\title{
Board characteristics and company performance: Evidence from Nigeria
}

\author{
Edem Okon Akpan', Noor Afza Amran² \\ ${ }^{1}$ Othman Yeop Abdullah Graduate School of Business, Universiti Utara Malaysia, Sintok Kedah, Malaysia \\ ${ }^{2}$ School of Accountancy, College of Business, Universiti Utara Malaysia, Sintok Kedah, Malaysia
}

\section{Email address:}

akpanzion2000@yahoo.com (Akpan, E. O.), afza@uum.edu.my(Amran, N. A)

\section{To cite this article:}

Edem Okon Akpan, Noor Afza Amran. Board Characteristics and Company Performance: Evidence from Nigeria. Journal of Finance and Accounting. Vol. 2, No. 3, 2014, pp. 81-89. doi: 10.11648/j.jfa.20140203.17

\begin{abstract}
This study examines the relationship between board characteristics and company performance (measured by turnover) in Nigeria. The study uses multiple regression technique on 90 sampled firms from the main board of Nigerian Stock Exchange from 2010 to 2012. The empirical evidence shows that board size and board education are positively and significantly related to company performance. While there is no relationship between board equity, board independence, and board age. Also, this study evidences a negative significant between board women and turnover. Their appointment is window dressing as the percentage is too small for meaningful positive effect on company performance. Based on this finding, the study recommends legislation mandating companies listed on Nigerian Stock Exchange to appoint at least 30 to 35\% of women on the board of directors.
\end{abstract}

Keywords: Corporate Governance, Board Characteristics, Company Performance, Nigeria

\section{Introduction}

The globalization of business practices and financial crisis brought corporate governance to the fore front of research. The increased attention on corporate governance has been motivated by the collapse of great corporations like WorldCom and Enron. Most countries have made significant effort to strengthen their corporate governance, transparency and disclosure levels. The collapse of the Nigerian financial institutions was as a result of poor corporate governance standard, corruption and lack of transparency. Shareholders lost confidence totally in both public and private companies in the country as a result of weak corporate governance practice in the country. In order to gain back the confidence, Security and Exchange Commission came up with the Code of Best Practice. It provides guidelines on the principles of corporate governance in Nigeria. Therefore, a good system of corporate governance is considered as an important element in running the affairs of the company for the best interest of the shareholders. It assists in controlling the performance of the board in business operations. The board of director has a part to play in corporate governance as their main duty is that of supervising the management to ensure proper accountability to shareholders and other stakeholders. Since the board of director is vested with the responsibility of monitoring the interest of shareholders, they ought to have greater interest in the appointment of directors to ensure that qualified, experienced and educated directors are appointed. Individual firms apart from the SEC (2006) requirements have specified the profile requirements expected of their directors. The problem now is whether the board characteristics influence firm performance. Studies have shown that corporate governance can be measured through board size, board women, CEO duality, board education, working experience, outside directors, compensation and block holders (Vo \& Phan, 2013). Several studies have examined the impact of CEO duality, board composition, board size, board independence on firm performance. In Nigeria, studies like Sanda, Mukailu, and Garba (2005), Ehikioya (2009), Babatunde and Olaniran (2009), Kajola (2010), and Akhalumeh, Ohiokho, Ohiokha (2011) have studied corporate governance and firm performance, but did not consider the elements of gender, age and educational qualification. Therefore, this study aims to examine the influence of board characteristics on firm performance in Nigeria. The reason for the choice of board characteristics is that, it is an important tool or mechanism for monitoring and advising, management of corporations to 
managing the affairs of the business for the benefit of shareholders (Fama \& Jensen, 1983). This study contributes to existing literature by providing empirical evidence on the relationship between board characteristics and firm performance in Nigeria. Secondly, it adds to the framework by using turnover as a measurement of firm performance. The remainder of this paper is structured as follows: Section two provides the review of current related literature on board characteristics. The next section focuses on the methodology and the fourth section discuses research model and measurement. While analyses and finding of the study is discussed in section five. The final section suggests possible limitations of the study and concludes the study.

\section{Review of Literature and Hypotheses Development}

\subsection{Board Size}

Board size is the number of directors on board. There are two schools of thoughts - small and large board size, but there is no agreement on which of them is better. Researchers in the first school of thought are of the opinion that small board size contributes more to the success of a company (Lipton \& Lorsch, 1992; Jensen, 1993; Yermack, 1996). Furthermore, Yermack (1996) argued that large board is slow in decision making and time wasting. The second school of thought argues that large board size improve company performance (Pfeffer, 1972; Klein, 1998). Large board size enables board to gather more information. However, the number of directors on board seems to have influence on firm performance. Abor (2007) reported positive relationship between board size and leverage. Based on the above arguments, it is hypothesized that:

$H_{1}$. There is significant relationship between board size and company performance.

\subsection{Board Independence}

Board independence refers to a corporate board with majority of outside directors. It is believed that dominated by outside or independence directors are more vigilant in monitoring behaviors and decision making of the company (Fama and Jensen, 1993). The reason is that shareholders interest could be well protected by outside directors than the inside directors. They bring in more skills and knowledge to the company which increases expertise necessary for strategy implementation (Kamardin, 2011). For Independent directors to perform their duties well they must be free from management's influence. The effective monitoring by independent directors reduces agency costs and increase company performance (Fama, 1980). The presence of independent directors on board gives greater weight to board's deliberations and judgment (Heravia, Saat, Karbhari, \& Nassir, 2011).

However, in carrying out their duties of monitoring, independent directors face great challenge as they are not directly affiliated with the management (Weisbach, 1988). The fact that independent directors are on board does not guarantee good governance control. It may be possible some independent directors are appointed to just fulfill the minimum regulatory requirements. Some of them may not be truly independent from the firm's executives who hire them or they might have developed strong friendship with the top management over the period they have served on the board. In order to maintain board independent, SEC (2006) spelt out conditions form appointment of independence directors as follows:

- Is one that is free from any relation with the company that may affect his ability to make independent judgments;

- Is not a partner or an executive of the company's statutory audit firm, equal or consulting firms that associate with the company for three years preceding his appointment;

- Should have no business dealings that could impair his capacity to act in an independent manner;

- Should not be a vendor, supplier or customer of the company;

- Is one who is not be a member of the immediate family of an individual who is or has been in the employment of the company for the past three years;

- Has not served the company in any capacity or been employed by the company for the preceding three financial years;

- Is not a representatives of a shareholders that has ability to control management and;

- Should not be one whose shareholding both direct and indirect does not exceed $1 \%$ of the company's paid up capital.

John and Senbet (1998) opined that a board is more independent if it has more non-executive directors. Other studies such as Agrawal and Knoeber (1996) have shown relationship between independent directors and company performance. Hence it is hypothesized that:

$\mathrm{H}_{2}$. There is a significant relationship between board independence and company performance.

\subsection{Board Age}

Boards with different age groups are of great benefit to the organization. Hambrick and Mason (1984) argued that companies with young managers experience higher growth than companies with older managers. Young managers have the tendency not to accept status quo but willing to accept new ideas (Cheng, Chan and Leung 2010). Studies that examine the relationship between directors age and company performance are limited. Findings of age diversity and company performance are reported differently. Mahadeo et al. (2012) reported a positive association between age different age groups on board and company performance. Age diversity significantly and positively affects corporate performance when measured by ROA (Dagsson, 2011). Ararat et al. (2010) found age diversity significantly affect return on equity using data from Turkish 
firms. Kidduff, Angelmar and Mehran (2000) found a positive relationship between age and marketing performance, but Randoy, Oxelheim \& Thomsen (2006) and Eklund, Palmberg \& Wibery (2009) found no significant influence of age on Tobin's Q. Based on prior findings that higher proportion of young directors on board is positively related to performance. Thus, we hypothesized that;

$H_{3}$. There is a significant relationship between age diversity and company performance.

\subsection{Board Education}

Board of directors is responsible for monitoring management on behalf of shareholders. For this reason, the shareholders ought to ensure that the board is staffed with educated members that would not allow their investment to be wasted. Companies as well as the Nigerian Corporate Governance Code precisely spelt out the requirements expected for the directors. Business organizations formed and managed by educated managers tend to perform better than those managed by uneducated managers. Many studies on board characteristics are silent on the educational qualification of board members. Educational qualification of directors is important for decision making. Studies have found positive relationship between director's qualification and firm performance. Ujunwa (2012) finds a positive and significant relationship between directors with $\mathrm{PhD}$ and company`s financial performance in Nigeria using data from 122 listed companies on the Nigerian Stock Exchange from 1991 to 2008. Yermack (2006) found that share price reactions to director's professional qualification, especially in the area of accounting and finance. Haniffa \& Cooke (2002) found a positive relationship between accounting education of board members and disclosure of information. Based on the argument above, it is hypothesized that:

$H_{4}$.There is a significant relationship between director's professional/educational qualification and company performance.

\subsection{Board Equity}

One of the characteristics of modern companies is the separation of ownership and control. This leads to conflict of interests between managers and owners. Owners are interested in wealth maximization while managers are concerned with personal wealth and prestige. In order to align interest of both parties directors are given shares, stock option, and compensation. Director equity ownership is an incentive to directors to enable them monitor managers effectively (Brickley et al., 1988). When directors own shares in the company, they will like to take actions that will increase both their wealth and that of the shareholders (Booth et al., 2002). Substantial shares ownership by board members creates a personal based incentive to actively monitor management. Bharbra et al. (2003) reported a positive association between director stock ownership and corporate performance. Bhagat, Carey and Elson (1998) also reported a significant correlation performance. Study by
Jensen and Murphy (1990) found a positive correlation between CEO shares and company performance. Hence it is posited that;

$H_{5}$. There is a significant relationship between Executive Director (ED) and Non-Executive (NED) director equity ownership and company performance.

\subsection{Board Women}

Studies on women on board have received attention in recent years and have contributed to legislation in some countries that made reservation for women in the board of listed companies. For instance, Norway and Sweden imposed gender quota on board of directors of listed companies (Rondoy, Oxelheim and Thomson, 2006). Also, the United State Security and Exchange Commission mandated all listed companies to encourage diversity in the appointment of board members (Upadhyaya and Puthenpyrackal, 2013). The presence of women on board is increasing. According to Catalyst (2010), women hold about $15 \%$ of board seats in Fortune 500 companies in 2010, while they also occupied $9.4 \%$ board seats of French companies (Dang \& Vo, 2012). Women on board can increase effectiveness of board control as they are more strict and trustworthy than their male counterparts. Their participation in board governance can help to avoid risky projects as they are generally more financial risk-averse than men (Byrness et al., 1999). Most companies select women into board based on the resource to which they can provide access (Hillman et al., 2007). They bring resources such as prestige, skills, knowledge, and connection to external resources (Dang \& Vo, 2012).

Several studies have been conducted to establish the relationship between board women and company performance but findings of these studies are mixed. Carter et al. (2003); Luckerath-Rover (2011) found positive significant relationship between women directors and firm performance. Smith, Smith and Verner (2006) found significant effect of women on firm performance while Ferreira (2009) found negative significant relationship. Bohren and Strom (2007), and Bar, Niessen and Ruenzi (2008) also found a negative relationship between gender and fund returns. Gregory-Smith et al. (2012) used UK firms from 1996 to 2010 found no significant effect both with ROA and ROE. Durmadi (2011) found a negative effect of female directors on both ROA and Tobin's q using 169 Indonesian firms in 2007. Minguez-Vera \& Martin (2011) found a significant negative relationship between female directors and firm performance measured by ROE using sample of small and medium Spanish enterprises from 1998 to2003. Similar results were obtained from studies of Dwyer et al. (2003), Randoy et al. (2006), Rose (2007) and Marinova, Plantenga and Remery (2010). Hence it is hypothesized that:

$H_{6}$. There is a significant relationship between board women and company performance. 


\section{Methodology and Data}

\subsection{Research Design}

This study adopted a quantitative research approach where data was gathered through secondary approach.

\subsection{Population and Sampling Technique}

The population of this study is all listed companies on the Nigerian Stock Exchange from 2010 to 2012. A total of 119 companies were active within the period under consideration with complete annual report and financial statements that end at 31 st December. The sample size of this study was 90 companies this sample size was arrival at by using Krejice and Morgan (1970) rule of thumb. A simple random sampling technique was used to select the 90 companies which data was collected for the study. Sample was drawn from ten sectors namely: Agriculture and Agro Allied, Conglomerate, Consumer Goods and Services, Construction and Real Estate, Healthcare Services, Information and Technology, Industrial goods, Natural Resource, Oil and Gas, Service and Financial Institutions. The reason for using those sectors is to ensure that all industries are included.(See table 1)

\subsection{Data Collection}

This study uses a secondary data; data was collected from the company's annual reports and financial statements. This is consistent with other studies that made use of company's annual reports as their main source of data (Hashim and Devi, 2010; Shukeri et al., 2012; Ponnu, 2008; Sanda et al., 2005). Information on board characteristics such as board size, board independence, board age, board education, gender diversity and board equity were all collected from the annual reports.

\subsection{Research Model and Measurement}

The independent variables for this study are board size, board independence, board age, board equity, board education and gender diversity. The dependent variable is company performance measured by turnover. This is consistent with Hanoku (2008) and Wakefield and Castillo (2005). Operationalization of variables are as follows: board size (Bsize) is the total number of directors on board, board independence (Bind) is the number of independent directors on board divided by the total number of directors, board age (Bage) is the number of young directors between the ages of 25 to 45 years divided by the total number of board. Board education (Bedu) is measured by the percentage of directors with higher educational qualification (Master and $\mathrm{PhD}$ ) divided by the total number of directors. Board equity (Bequity) is measured by the number of shares owned by both independent and non-independence directors as a percentage of the total shares of the company. Gender diversity (Gend) is measured as the number of women divided by the total number of directors. Turnover is the total sales for the period scaled down by one billion. Scaling is a common mathematical practice to reduce values to a manageable size. According to Wooldridge (2009) data scaling is used for cosmetic purposes to reduce and improve data appearance while changing nothing that is important. The model for this study is as stated below:

Company performance $=\beta_{0}+\beta 1$ Bsize $+\beta 2$ Bind $+\beta 3$ Bage + $\beta 4$ Bedu $+\beta 5$ Bequity $+\beta 6$ Gend $+\varepsilon$

Where

Company performance $=$ Turnover for the period

Bsize $=$ Number of directors on board

Bind $=$ Percentage of independent directors on board

Bage $=$ Percentage of young directors on board

$\mathrm{Bedu}=$ Percentage of directors with master degree and $\mathrm{PhD}$

Bequity $=$ Percentage of directors equity

Gend $=$ Percentage of women directors on board

$\varepsilon=$ Error term

Table 1. Industrial Classification

\begin{tabular}{lll}
\hline Industry & $\begin{array}{l}\text { Number of } \\
\text { company }\end{array}$ & Percentage \\
\hline Agriculture \& Agro Allied & 3 & 3 \\
Conglomerate & 3 & 3 \\
Consumer goods and services & 17 & 19 \\
Construction and real estate & 5 & 6 \\
Health care services & 4 & 5 \\
Information and technology & 4 & 5 \\
Industrial goods & 10 & 11 \\
Natural resources & 3 & 3 \\
Oil and gas & 8 & 9 \\
Services & 13 & 14 \\
Financial institutions & 20 & 22 \\
Total & $\mathbf{9 0}$ & $\mathbf{1 0 0 \%}$ \\
\hline
\end{tabular}

Source: Nigerian Stock Exchange fact book 2011/2012

\section{Result and Discussion}

\subsection{Descriptive Analysis}

Table 2. Descriptive Statistics.

\begin{tabular}{lccc}
\hline Variables & N & Mean & Std. Deviation \\
\hline TURNOVER & 270 & 27.75 & 48.291 \\
BSIZE & 270 & 9.73 & 2.907 \\
BIND \% & 270 & 45.35 & 24.721 \\
BAGE & 270 & 7.75 & 12.259 \\
BEDU & 270 & 10.75 & 14.785 \\
BEQUITY & 270 & 15.79 & 20.932 \\
BWOMEN & 270 & 10.74 & 8.859 \\
\hline
\end{tabular}

Table 2 shows the mean and standard deviation values of all the variables used in the study. The sample size used in the analysis was 90 companies selected from the Nigerian Stock Exchange from 2010 to 2012 with a total number of 270 observations. The result shows that mean for all the 
variables fall within the range of 8 to $45 \%$ and the standard deviation within 2.9 to 24.7 . The mean board size is 9.73 , meaning that for every board there is about 10 directors. This result is higher than New Zealand 5.81 and Australia 6.6 but less than US which is 11.45 (Bhagat and Black,
2000 ). The mean board independence is $45.3 \%, 10.75 \%$ of directors have master degree, $10.74 \%$ of board members are women, and $7.75 \%$ of directors are between the age of 25 to 45 years.

\subsection{Correlation Analysis}

Table 3. Correlation result

\begin{tabular}{|c|c|c|c|c|c|c|c|}
\hline Variable & T/Over & BSIZE & Bind & Bage & Bedu & Bequity & Bwomen \\
\hline $\mathrm{T} /$ over & 1 & & & & & & \\
\hline Bsize & $.183 * *$ & 1 & & & & & \\
\hline Bind & -.061 & .042 & 1 & & & & \\
\hline Bage & -.020 & $-.205 * *$ & -.041 & 1 & & & \\
\hline Bedu & $.134 *$ & .030 & .069 & $.162 * *$ & 1 & & \\
\hline Bequity & -.094 & -.099 & -.008 & $.147 *$ & .034 & 1 & \\
\hline Bwomen & -.080 & .010 & -.035 & $.195 * *$ & $.185^{* *}$ & .112 & 1 \\
\hline
\end{tabular}

$* * \mathrm{p}<0.01 ; * \mathrm{p}<0.05$ at 2 tailed levels.

The main aims of this analysis are to identify the relationship among the variables and whether there is a multicollinearity problem. Multicollinearity exists when two or more variable are highly correlated. According to Tabachnick and Fidel (2007) correlation exceeding 0.9 may affect accuracy of the multi-regression test result. In this study the highest correlation is between board women and board age 0.195 which indicates that multi-collinearity would not affect the result. Correlation between board size and Turnover is .183 , board age with board size -.205, while board equity with board age is .147 . Board edu correlate with Turnover at .134 and board age at .147.

\subsection{Multiple Regression Analysis}

Table 4. Multiple regression result.

\begin{tabular}{lccc}
\hline Variables & Beta & t & Sig \\
\hline Constant & - & .727 & .468 \\
BSIZE & .180 & 2.941 & .004 \\
BIND & -.082 & -1.378 & .169 \\
BEQUITY & -.073 & -1.201 & .231 \\
BWOMEN & -.109 & -1.766 & .078 \\
BAGE & .021 & .328 & .743 \\
BEDU & .153 & 2.501 & .013 \\
\hline
\end{tabular}

Predictors: (Constant), BEDU, BSIZE, BCOMP, BEQUITY, BWOMEN, BAGE, Dependent Variable: Turnover

Table 4 shows the result of board characteristics and company performance as measured by turnover. The value of the turnover was scaled down by one billion; this is a common practice in mathematics to scale down numbers that are high to a manageable size. $\mathrm{H} 1$ predicts a significant association between board size and company performance, the coefficient is positive and significant at $\beta=.180, p<.004$ This result implies that board size positively enhanced company performance and thus supports the hypothesis that there is a significant relationship between board size and company performance. This implies that large board size is beneficiary to the company in terms of attracting resources and contributions of skills, experiences and expertise to the financial performance of the company.

Hypothesis 2 states that there is a significant relationship between board composition and company performance. The study found a negative relationship but not significant, hence the alternate hypothesis is rejected. This finding is in line with Tacherva and Huse (2006) that board composition does not usually matter much to company performance but rather effects individual board task performance.

Hypothesis 3 predicts a significant association between younger directors and company performance. This was measured by the number of young directors over the total number of directors on the board. The result shows no evidence to support those directors between the ages of 25 to 45 years effect company performance. It indicates that young directors between the ages of 25 and 45 years of age lack experience and managerial skills necessary to improve performance positively. The alternate hypothesis is hereby rejected.

Hypothesis 4 states that there is a significant relationship between directors' educational qualification and company performance. The regression result shows $\beta=.153, p<.013$, explains that there is a significant relationship between directors' qualification and company performance. This implies that educational qualification equip directors with knowledge, experience and better managerial and administrative skills in the conduct of the company`s affairs.

Hypothesis 5 hypothesized that directors share ownership significantly influence company performance. Directors' shares ownership was measured by the number of shares held by directors divided by the total shares in issue. The results shows a negative association but not significant and thus the result support not the hypothesis. This indicates that there is an agency problem of entrenchment where directors of the sampled companies may undertake projects that will benefit them than the shareholders. 
Hypothesis 6 states that there is a significant relationship between gender diversity and company performance, however the result shows a negative significant $(\beta=-.109$, $p$ $<.078$ ). This result is in line with Adams and Ferreira (2009) that found negative relationship with financial performance and gender diversity. The reason for the negative relationship could be attributed to the performance measurement and the limited number of women on board. Appointment of women into board sometimes is window dressing to portray the company image of gender sensitive.

\subsection{Discussions}

The empirical result of board size provides a positive significant relationship with firm performance. This result supports the previous finding by Hanoku (2008). Dagsson (2011) found a similar results when board size significantly and positively affect return on asset (ROA) but significant negative affect Tobin's $Q$ in his study on how age diversity on board of directors affect firm performance. In the study, large board size was believed to enhance or improved the board independence. The mean board size is 9.7; this may be considered as small in the Nigeria context but companies must be careful as sizeable number of board members which are considered as the agents tend to be much concerned about their interests (Uwuigbe and Fakile, 2012). Result on board composition shows no significant relationship with company performance and consistent with claims of Forsberg (1989) and $\mathrm{Pi}$ and Timme (1993) that there is no significant relationship between board composition and company performance. The result on women on board revealed a negative significant relationship with company performance. This finding support Adama and Ferriera (2009) that also found negative significant relationship. Durmadi (2011) found negative effect of female directors on both ROA and Tobin's Q. Using sample of small and medium Spanish enterprises Minguez-Vera and Martin (1022) also found significant negative relationship between female directors and firm performance measured by ROE. This means that women on board is window dressing, they are appointed to fulfill all righteousness but do not contribute positively to company performance. The possible reason for the negative finding on the women on board could be attributed to different performance measurement. The finding on board age revealed a positive but not significant influence on the firm performance measured by turnover. Director equity was not significant dis-proving the belief that compensating directors with shares would align their interests with that of shareholders. Instead they are given more power to embark on projects are beneficiary to them than the shareholder. Empirical result on directors higher educational qualification (Master degree and $\mathrm{PhD}$ ), their presence was significantly and positively related with firm performance. This finding is consistent with Amran (2010) and Ujunwa (2012) that directors with degree significantly affect firm performance. This implies that educational qualification equip director with knowledge, experience and better skills (managerial and administrative) to conduct the affairs of the company.

\section{Conclusion}

The aim of this research was to empirically investigate the influence of board characteristics on the company performance. A sample of 90 quoted companies in the Nigerian Stock Exchange was drawn from a period 2010 to 2012. Results from this study shows that board size has positive significant influence on company performance. Another feature of the result is that the finding that board women had a negative significant influence on company performance while board education is positively significant. On the other hand, board equity, board age and board independence were found insignificant. Based on the findings of the study, the following recommendations were made:The Federal government of Nigeria and its regulatory agencies should encourage appointment of women as directors by enacting law that will mandate listed companies in Nigeria to appoint at least 30 to $35 \%$ of women into board of directors. The government should ensure that both executive and nonexecutive directors should not own more than $1 \%$ in equity in issue; this will reduce the problem of entrenchment.

The sample used in this study was limited to the number of companies listed on the main market of the Stock Exchange. The sample size was small because of the number of listed companies as at the time of the study. Firms with in-complete reports and those whose accounting period was not aligning the period of study were excluded. One of the methods of obtaining information on women on board was through the use of pictures of board members as contained in the annual reports. However, some companies do not include the pictures of the board members in their annual reports. Thus, it is difficult to identify them. Future researcher may consider expansion of the model and introduction of moderating variables for better results than this.

\section{References}

[1] Abor, J. (2007). Corporate governance and financing decisions of Ghanaian listed firms: Corporate governance. International Journal of Business in Society, 22(1), 83-92.

[2] Adams, R. \& Mehra,.H. (2002). Board structure and banking firm performance. Working Paper, Federal Reserve Bank of New York.

[3] Adams, R. B., \& Mehran, H. (2005).Corporate performance, board structure and its determinants in the Banking Industry.EFA 2005 MOSCOW Meetings.

[4] Adams, R.B., \& Ferreira, D. (2009).Women in the boardroom and their impact on governance and performance. Journal of Financial Economics, 94(2), 291-309.

[5] Agrawal, A., \& Knoeber, C. (1996). Firm performance and mechanisms to control agency problems between managers and shareholders. Journal of Financial and Quantitative Analysis, 31, 377 - 403 . 
[6] Akhalumeh, P., Ohiokho, F., \& Ohiokha, G. (2011). Board composition and corporate performance: An analysis of evidence from Nigeria. Research Journal of Finance and Accounting, 2(4), $64-73$.

[7] Amran, N. A., \& Ahmad, A. C. (2010).Corporate governance mechanisms and performance: Analysis of Malaysian family and non-family controlled companies. Journal of Modern Accounting and Auditing, 6(2), $1-15$.

[8] Ararat, M. Aksa, M., \& Cetin, A. T. (2010). Impact of board diversity on board monitoring intensity and firm performance: Evidence from the Istanbul Stock Exchange. Paper Presented at the $17^{\text {th }}$ Annual Conference of the Multinational Finance Society $27-30$ June Barcelona, available at: http://paper.ssrn.com/50/3/paper.cfm?abstractid $=1572$ 283 _ accessed 26 June 2013.

[9] Babatunde, A., \& Olaniran, O. (2009). The effect of internal and external mechanisms on governance and performance of corporate firms in Nigeria. Corporate Ownership and Control, 7(2), $330-340$.

[10] Bär, M., Niessen, A., and Ruenzi, S. (2009), "The impact of team diversity on mutual fund performance", working paper, Centre for Financial Research, University of Cologne, Cologne, February.

[11] Bhabra, G. S., Ferris, P. S., Seri, N. (2003). Corporate governance in Singapore: The impact of director equity ownership. Advance in Financial Economics, 8, 29 - 46.

[12] Bhagat, S., Carey, D., \& Elson, C. M. (1998).Director ownership corporate performance and management turnover. Business Lawyer, 54(3), 885 - 919.

[13] Bhugat, S., \& Black, B. (2002).The non-correlation between board independence and long term firm performance. Journal of Corporation Law, 27(2), 231 - 274.

[14] Black, B. S., Jang, H., \& Kim, W. (2006). Does corporate governance predict firms' market values? Evidence from Korea. Journal of Law, Economics, and Organization, 22(2), 366-413.

[15] Bøhren, Ø. and Strøm, R. (2007), "Aligned informed and decisive: Characteristics of valuecreating boards", working paper, Norwegian School of Management, Oslo, 12 February.

[16] Booth, J. R., Cornett, M. M., \& Tehranian, H. (2002). Boards of directors, ownership and regulation. Journal of Banking and Finance, 26, 1973 - 1996.

[17] Carter, D.A., Simkins, B.J., \& Simpson, W.G. (2003), Corporate governance, board diversity, and firm value. Financial Review, 38(1), 33-53.

[18] CBN (2006). CBN Code of Corporate Governance for Banks in Nigeria Post Consolidation, Nigeria Abuja

[19] Cheng, L. T. W., Chan, R. Y. K., \& Leung, T. Y. (2010). Management demography and corporate performance: Evidence from China. International Business Review and Quantitative Analysis, 42(4), 941 - 962.

[20] Creswell, J. W. (2009). Research design: Qualitative, quantitative and mixed methods approach (3rd ed.). Thousand Oaks: Sage Publications.

[21] Dagsson, S. (2011). How age diversity on the board of directors affects firm performance. (Unpublished Thesis).

[22] Darmadi, S. (2011). Board diversity and firm performance: The Indonesian evidence. Corporate Ownership and Control. 9(1), 524-539.

[23] Dwyer, S., Richard, O.C., and Chadwick, K. (2003), "Gender diversity in management and firm performance: the influence of growth orientation and organizational culture", Journal of Business Research, 56(12), 1009-1019.

[24] Ehikioya, B. I. (2009). Corporate governance structure and firm performance in developing economies: Evidence from Nigeria. Corporate Governance, 9(3), 231 - 243.

[25] Eklund, J. E., Palmberg, J., \&Wiberg, D. (2009).Ownership structure, board composition and investment performance.Working Paper, Center for Excellence for Science and Innovation Studies. Stockholm, March, 2009.

[26] Fama, E. F. (1980). Agency problems and theory of the firm. Journal Political Economics, 88(2), 288 - 307.

[27] Fama, E. F., \& Jensen, M. C. (1983).Agency problems and residual claims. Journal of Law and Economics, 26, 327 349.

[28] Fama, E. F., \& Jensen, M, (1983). Separation of ownership and control. Journal of Law and Economics, 26(2), $301-$ 325 .

[29] Farrell, K. A., \& Hersch, P. L. (2005). Additions to corporate boards: the effect of gender. Journal of Corporate Finance, 11, 85-106.

[30] Gregory-Smith, I., Brian, G. M., Charles, A. (2012). Appointing women to the board in the UK. Working Paper.

[31] Hambrick, D. C., \& Mason, P. A. (1984). Upper Echelons: The organizations as a reflection of its top managers. Academy of Management Review, 9(2), 193 - 206.

[32] Haniffa, R. M., \& Cooke, T. E. (2002). Culture, Corporate Governance and Disclosure in Malaysian Corporations. Abacus, 38(3), 317-349.

[33] Hanoku, Bathula (2008). Board characteristics and firm performance: Evidence from New Zealand. Unpublished Thesis.

[34] Hashim, H. A., \& Devi, S. S. (2010). Corporate governance, ownership structure and earnings quality: Malaysian evidence. Working Paper, University Malaya.

[35] Heravia, S., Saat, N. M., Karbhari., Y. \& Nassir, A. (2011). Effective Oversight Roles of Board of Directors: The case of listed firms on Bursa Malaysia. World Review of Business Research, 1(1), $231-245$.

[36] Hermalian, B. \&Weisbach, M. (2003). Boards of directors as an endogenously determined institution: A survey of the economic literature. Economic Policy Review, 7 - 25.

[37] Hermalin, B. E., \&Weisbach, M. S. (2001). Boards of directors as an endogenously determined institution: A survey of the economic literature (No.W8161). National Bureau of Economic Research.

[38] Hillman, A. \&Dalziel, T. (2003). Boards of directors and firm performance: Integrating agency and resource dependency perspective. Academy of Management Review, 28 (3), 383-396 
[39] Hillman, A. J., Cannella, A. A., \&Paetzold, R. L. (2000). The resource dependence role of corporate directors: Strategic adoptation of board composition in response to environmental change. Journal of Management Studies, 7, 235-255.

[40] Huse, M., \& Solberg, A. G. (2006). Gender related boardroom dynamics: How Scandinavian women make and can make contributions on corporate boards. Women in Management Review, 21(2), 113 - 130.

[41] Jensen, M. C. (1993). The modern industrial revolution, exit, and the failure of internal control systems. Journal of Finance, 48(3), $831-80$.

[42] Jensen, M. C., \& Meckling, W. H. (1976). Theory of the firm: Managerial behavior, agency costs and ownership structure. Journal of Financial Economics, 3(4), 305 - 360.

[43] Jensen, M. C., \& Murphy, K. (1990). Performance Pay and Top-Management Incentives. Journal of Political Economy, 98(2), $225-264$

[44] Puthenpurackal, J. Upadhyay, A .(2013). Board gender diversity and firm performance: The impact of information environment. Available www.efmaefm.org/.../BoardGenderDiversity_Puthenpurack

[45] John, K., \& Senbet, L. W. (1998). Corporate governance and board effectiveness. Journal of Banking and Finance, 22, 371 -403 .

[46] Kajola, S. A. (2010). Corporate Governance and Firm Performance: The Case of Nigeria listed firms. European Journal of Economics, Finance and Administrative Science, (14)16-28.

[47] Kamardin, H., \& Haron H. (2011). Roles of Board of Directors: Monitoring and resource dependency perspectives from Malaysia. International Journal of Economics and Accounting, 2(3), $282-306$.

[48] Kilduff, M., Angelmar, R., \&Mehran, A. (2000). Top management: Team diversity and firm performance: Examining the role of cognitions. Organization Science, 2(1), $21-34$.

[49] Klein, A. (1998). Firm performance and board committee structure 1.Journal of Law and Economics, 41(1), 275 - 304.

[50] Letendre, L. (2004). The Dynamics of the boardroom.Academy of Management Executive, 18(1), 101104.

[51] Lipton, M., \& Lorsch, J. W. (1992). A modest proposal for improved corporate governance, Business Lawyer, 48( 1), 59-77.

[52] Lu"ckerath-Rovers, M. (2010). A comparison of gender diversity in the corporate governance Codes of France, Germany, Spain, the Netherlands and the United Kingdom. Available at SSRN: http://www.ssrn.com/abstract=1585280,

[53] Marinova, J., Plantenga, J., \& Remery, C. (2010), Gender diversity and firm performance: Evidence from Dutch and Danish boardrooms. Discussion paper, University of Utrecht, Utrecht School of Economics, Utrecht, January.

[54] Mclntyre, M. L., Murphy, S. A., \& Mitehell, P.(2007).The top team examining board composition and firm performance, corporate governance. The International Journal of Effective Board Performance, 7(5), 547-561.

[55] Mehran, H. (1995). Executive compensation structure, ownership and market valuation: An empirical analysis. Journal of Financial Economics, 20, 293 - 315.

[56] Minguez-Vera, A., Martin, A. (2011). Gender and management on Spanish SME`s: An empirical analysis. The International Journal of Human Resource Management. 22(14), 2852-2873.

[57] Nigerian Stock Exchange (2006). Fact books, various issues, Lagos Nigeria.

[58] Pearce, J. A., \& Zahra, S. A. (1992). Board composition from a strategic contingency perspective. Journal of Management Studies, 29(4), $411-438$.

[59] Pfeffer, J. (1972). Size, composition of corporate boards of directors: The organization and its environment. Administrative Science Quarterly, (1972) 218 - 228.

[60] Pi, L, Timme, S. (1993). Corporate control and bank efficiency.Journal of Banking and Finance, 17, 515 - 30.

[61] Ponnu, C. H. (2008). Corporate governance structure and the performance of Malaysia public listed companies. International Review of Business Research Papers, 4(2), $217-230$.

[62] Randøy, T., Oxelheim, L., \& Thomsen, S. (2006). A Nordic perspective on corporate board diversity. Working Paper, Nordic Innovation Centre, Oslo, November.

[63] Rose, C. (2007). Does female board representation influence firm performance? The Danish evidence. Corporate Governance, 15(2), $404-413$.

[64] Sanda, A. U, Mukaila, A. S \& Garba, T. (2005): Corporate governance mechanisms and firm financial performance in Nigeria. AERC Research Paper, No 149.

[65] Sebora,T. C. \& Wakefield, M. W. (1998). Antecedents of conflicts over business issue in family firms. Journal of Entrepreneurship Education 1, 2-18

[66] Sekaran, U., Bougie, R. (2010). Research methods for business: A skill building approach $\left(5^{\text {th }}\right.$ ed.): John Wiley \& Sons Ltd

[67] Tabachnick, B. G., \& Fidell, L. S. (2007). Using multivariate statistics $\left(5^{\text {th }}\right.$ ed.). USA: Pearson Education Inc.

[68] Tacheva, S. \& Huse, M. (2006). Women directors and board task performance: Mediating and moderating effects of board working style. Conference Paper presented at European Academy of Management, Oslo, Norway.

[69] Ujunwa, A. (2012). Board characteristics and financial performance of Nigerian quoted firms. Corporate Governance, 12(5), $656-674$.

[70] Uwuigbe, O. R., Fakile, A. S. (2012). The effect of board size on financial performance of banks in Nigeria. International Journal of Economics and Finance, 4(20),260 - 267.

[71] Wakefield, M.W., \& Castillo, J. (2006). An exploration of firm performance factors in family business: Do families value only the "bottom line". Journal of Small Business Strategy, 17(2), $37-51$. 
[72] Weisbach, M. (1988). Outside directors and CEO turnover. Journal of Financial Economics, 20, 431 - 460.

[73] Wilson, I. (2006). Regulatory and institutional challenges of corporate governance in Nigeria post banking consolidation. Nigeria Summit Group (NESG) Economic indicators, April June 12(2) 1- 10 .

[74] Wooldridge, J. M. (2009). Introductory econometrics: A modern approach. ( $4^{\text {th }}$ ed.) USA Cengage Learning.
[75] Yermack, D. (1996). Higher market valuation of companies with a small board of directors. Journal of Financial Economics, 40(2), 185-211.

[76] Yermack, D. (2006). Board Members and Company Value. Financial Markets Portfoli Management, 20(1), 33-47 